\title{
Biosorption of Divalent ion onto Treated Prosopis Juliflora Bark from Aqueous Solutions: Isothermal and Statistical Analysis
}

\author{
N. MUTHULAKSHMI ANDAL*, S. CHARULATHA and N. S GAYATHRI
}

${ }^{1}$ Department of Chemistry, PSGR Krishnammal College for Women, Coimbatore-4, India.

*Corresponding author E-mail: andaldr@gmail.com

http://dx.doi.org/10.13005/ojc/320238

(Received: November 14, 2015; Accepted: December 29, 2015)

\begin{abstract}
The present work emphasizes the utilization of Prosopis juliflora bark, an agro waste material for the adsorption of $\mathrm{Cu}(\mathrm{II})$. The raw Prosopis juliflora bark (PJB) is treated using $0.1 \mathrm{~N}$ hydrochloric acid to enhance the sorption efficiency. The characterization studies of TPJB using Scanning Electron Microscopy (SEM), Energy Dispersive X-ray Analysis (EDAX), Brunauer-Emmet-Teller(BET) and Barrett-Joyner-Halenda (BJH) analyses carried out. The batch mode experimental set up is verified to assess the sorption capacity of the chosen material for the operating factors viz., particle sizes/ doses of the sorbent material upon a range of initial concentrations of $\mathrm{Cu}(\mathrm{II})$ at different temperatures, agitation time and $\mathrm{pH}$ of the $\mathrm{Cu}(\mathrm{II})-\mathrm{TPJB}$ system. The amount of $\mathrm{Cu}(\mathrm{II})$ ion adsorbed on to TPJB surface is found to be $43.11 \mathrm{mg} / \mathrm{g}(97.4 \%)$ under optimized conditions, its efficiency 3 fold times more than the $\mathrm{C}$ values reported by other researchers. The sorption characteristic of TPJB is quantitatively estimated through column experiments based on the $\mathrm{C}_{\mathrm{e}}$ value by batch mode. The removal is observed as $98 \%$. Langmuir, Freundlich and Tempkin isothermal curves at various initial concentrations are plotted for $\mathrm{Cu}$ (II)-TPJB system wherein the straight line fit is best suited for the Freundlich isotherm model. The results show that the response of TPJB in trapping $\mathrm{Cu}$ (II) ions are influenced by various parameters being statistically verified using SPSS software, indicative of good correlation.
\end{abstract}

Keywords: Adsorption, Characterization, Copper lons, Isotherms, Operating Factors.

\section{INTRODUCTION}

Rapid industrialization with the utilization of the heavy metals in industries viz., paints, pigments, batteries, ceramic glazes, electroplating and textiles ${ }^{1}$, over the past few decades has led to serious environment problems because of their increased disposal' ${ }^{2}$. Heavy metals like copper, nickel, zinc, cadmium, lead, chromium and mercury have been extensively employed in industries like paints, pigments, textile and electroplating industries, leading to higher concentrations in effluent discharges. Copper is a widely used metal in industries like mining, metallurgical, paints, 
pigments, electroplating and electronics ${ }^{3}$ The permissible limits recommended by WHO for Copper discharge in wastewater and drinking water are 0.05 and $0.005 \mathrm{mg} / \mathrm{L}$, only ${ }^{4}$. Beyond the permissible limit, it is declared carcinogenic and leads to ailments like gastrointestinal problems apart from headaches, fatigue, depression, skin rashes, learning disorders, the accumulation being in kidneys, brain, skin, pancreas and heart ${ }^{5}$.

The present work deals with the employment of Prosopis juliflora bark in adsorption of $\mathrm{Cu}(\mathrm{II})$ which has not been reported for any heavy metal removal so far in literature. Prosopis juliflora is a fast growing small tree in India. It is mainly cultivated and consumed for timber and furniture industries in the developing nations ${ }^{8}$.

\section{MATERIAL AND METHODS}

The collected Prosopis juliflora barks were washed well with distilled water, dried, pulverized using electrical mixer and categorized into different mesh sizes using scientific test molecular sieves, further treated with $0.1 \mathrm{~N} \mathrm{HCl}$ to enhance the sorption capacity, thereafter being referred as Treated Prosopis juliflora Bark (TPJB). TPJB with different

Table 1: Physicochemical Characteristics-TPJB

\begin{tabular}{|c|c|c|}
\hline Factors & $\begin{array}{c}\text { Methods } \\
\text { /Instruments }\end{array}$ & Values \\
\hline $\mathrm{pH}$ ( $1 \%$ solution) & $\mathrm{pH}$ meter & 5.62 \\
\hline Conductivity (Mv) & Conductivity Meter & 43.23 \\
\hline Bulk density $(\mathrm{g} / \mathrm{L})$ & Specific gravity bottles & 0.63 \\
\hline $\begin{array}{l}\text { Moisture Content } \\
(\%)\end{array}$ & Xylene & 5.97 \\
\hline Specific gravity & Pycnometer & 1.45 \\
\hline Porosity & BET & 56.55 \\
\hline $\begin{array}{l}\text { Ash content } \\
(\%)\end{array}$ & Muffle Furnace & 3.93 \\
\hline $\begin{array}{l}\text { Surface area } \\
(\mathrm{m} 2 / \mathrm{g})\end{array}$ & BET & 3.28 \\
\hline $\begin{array}{l}\text { Mean Pore diameter } \\
(\mathrm{nm})\end{array}$ & BET & 6.56 \\
\hline $\begin{array}{l}\text { Carbon } \\
(\%)\end{array}$ & CHNS Analyzer & 44.95 \\
\hline Hydrogen (\%) & CHNS Analyzer & 4.69 \\
\hline Nitrogen (\%) & CHNS Analyzer & 0.67 \\
\hline
\end{tabular}

mesh sizes $(0.18 \mathrm{~mm}, 0.21 \mathrm{~mm}, 0.30 \mathrm{~mm}, 0.42 \mathrm{~mm}$ and $0.71 \mathrm{~mm}$ ) were subjected to image microscopic analysis in order to determine the particle sizes of TPJB using Binocular Microscope (OLYMPUS make, Model- CX21I). The physio chemical characteristic studies employing various methods were performed and the values were registered. Morphology and elemental constitutions of the adsorbent material were identified using Scanning Electron Microscope (SEM) and Energy Dispersive X-ray Analysis (EDAX) (JEOL JFM- 6390).

\section{Batch Mode Adsorption Studies}

The agitation of $\mathrm{Cu}(\mathrm{II})$ ions with TPJB in a mechanical shaker (KEMI) was experimentally verified to define the role of variable parameters viz., particle sizes, $(0.71 \mathrm{~mm}, 0.42 \mathrm{~mm}, 0.30 \mathrm{~mm}, 0.21$ $\mathrm{mm}$ and $0.18 \mathrm{~mm}$ ) and dosages, (200 mg, $300 \mathrm{mg}$, $400 \mathrm{mg}$ and $500 \mathrm{mg}$ ) of TPJB, initial concentrations of the aqueous $\mathrm{Cr}(\mathrm{VI})$ ion solutions, $(20-100 \mathrm{ppm}$ : $20 \mathrm{ppm}$ intervals) preset time intervals between the sorbate and sorbent species, (30- $120 \mathrm{~min}: 30$

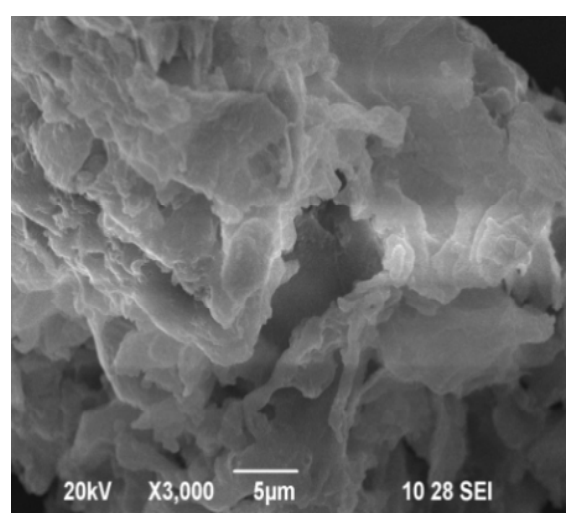

Fig. 1a: SEM-TPJB

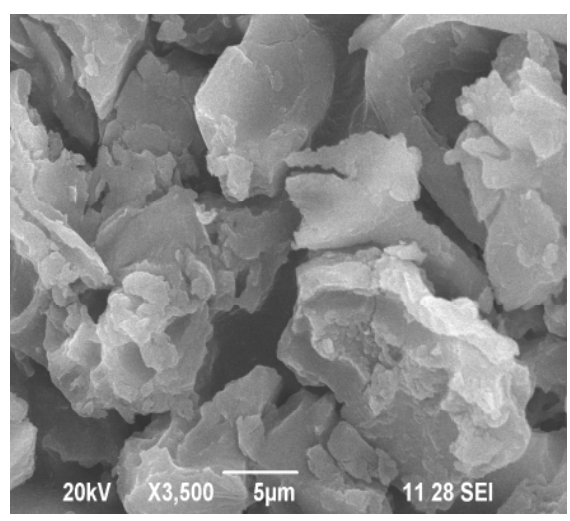

Fig. 1b: SEM-TPJB-Cu(II) 
were used for the evaluation of the particle and mesopore size distribution. Pore sizes are classified in accordance with the classification adopted by the International Union of Pure and Applied Chemistry (IUPAC manual., 1982) i.e) [micropores diameter $\left(d<20 A^{\circ}\right)$, mesopores $\left(20 A^{\circ}<d<500 A^{\circ}\right)$ and macropores $\left(d>500 A^{\circ}\right.$. Because of the larger sizes of liquid molecules, the adsorbents for liquid phase adsorbates should have predominantly mesopores in the structure ${ }^{9}$. The micropores are responsible for the large surface area $\left(3.28 \mathrm{~m}^{2} / \mathrm{g}\right)$ of TPJB, which is created by the activation process and the mean pore diameter is found to be $6.56 \mathrm{~nm}$. PJB is found to possess mesopores predominantly, as their pore diameter lie in the range of $20 A^{\circ}<d<$ $500 A^{\circ}$. The lesser ash content shows the presence of low quantity of inorganic matter and high quantity of the carbon content ${ }^{10}$. The amount $\mathrm{C}, \mathrm{H}$ and $\mathrm{S}$ contents present in TPJB are given in table 1. The physio-chemical characteristic of other adsorbents are given in table $1 \mathrm{a}$.

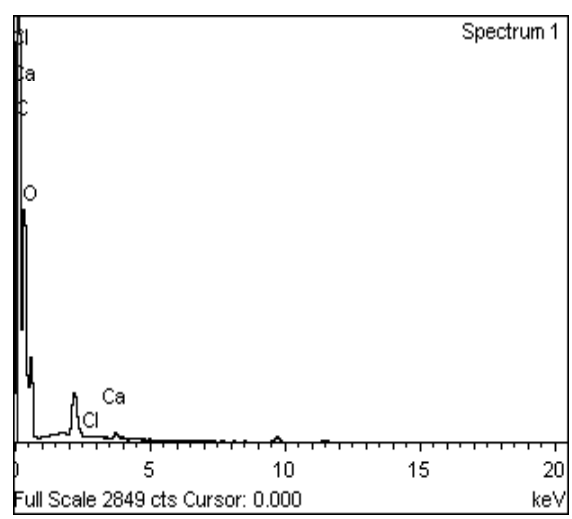

Fig. 2a: EDAX-TPJB

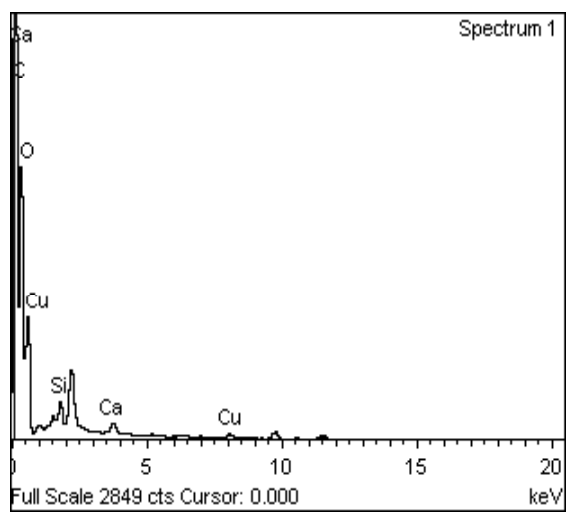

Fig. 2b: EDAX-TPJB- Cu(II) mins intervals) $\mathrm{pH}$ of the medium, ( $3,5,7,9$ and 11 ) and temperature of the system (293K- $333 \mathrm{~K}: 10$ $\mathrm{K}$ intervals) to assess maximum sorption capacity of the chosen material. The initial and residual concentrations of $\mathrm{Cu}(\mathrm{II})$ in solutions were analyzed using an Shimadzu (AA 6200) Atomic Absorption Spectrophotometer.

\section{Statistical Analysis}

The relationship between adsorbed $\mathrm{Cu}(\mathrm{II})$ ions and variable parameters was correlated using Pearson Moment Coefficient Method. The extend of statistical fit was verified using SPSS 20 software, the output variable being ANOVA, Pearson Correlation and descriptive analysis with a significance based on $95 \%$ confident level.

\section{RESULTS AND DISCUSSION}

\section{Physio- Chemical Characterization}

The registered physiochemical characteristic values of TPJB listed in table 1 are discussed as follows: The decreased bulk density value $(0.63 \mathrm{~g} / \mathrm{L})$ of TPJB may be the cause for enhanced adsorption of $\mathrm{Cu}(\mathrm{II})$ ions, implying the availability of large number of pores. The standardized bulk density and particle density values $<1.2$ and $<2.2$ respectively support the fine nature of TPJB. Moisture content value ( $\mathrm{H}^{\prime \prime}$ $5 \%$ ) indicates favorable adsorption, since the extent of sorption activity shows reduction upto $25 \%$. The porosity of TPJB is 56.55 , it is the measure of micro pore content of the material. BET and BJH methods

Table 1a: Physio chemical properties of some reported adsorbents

\begin{tabular}{|c|c|c|c|}
\hline \multirow[b]{2}{*}{ Factors } & \multirow[b]{2}{*}{$\begin{array}{l}\text { Rice } \\
\text { Husk }\end{array}$} & \multicolumn{2}{|c|}{ Values } \\
\hline & & $\begin{array}{c}\text { Mesquite } \\
\text { tree }\end{array}$ & $\begin{array}{c}\text { Aeromonas } \\
\text { hydrophila }\end{array}$ \\
\hline $\begin{array}{l}\mathrm{pH} \text { of } 1 \% \\
\text { solution }\end{array}$ & $6.3-6.5$ & 7.4 & 3.5 \\
\hline $\begin{array}{l}\text { Bulk density } \\
(\mathrm{g} / \mathrm{L})\end{array}$ & 0.31 & 0.82 & 0.119 \\
\hline $\begin{array}{l}\text { Moisture } \\
(\%)\end{array}$ & 8.25 & 3 & 6.8 \\
\hline Porosity & 0.38 & 54.95 & 0.629 \\
\hline $\begin{array}{l}\text { Ash content } \\
(\%)\end{array}$ & 18.39 & 3.9 & 4.28 \\
\hline Carbon (\%) & 30.56 & 40.65 & 25.79 \\
\hline
\end{tabular}




\section{Surface Morphology}

The surface morphological pictures of the unloaded and metal-loaded TPJB recorded using SEM are depicted in figures $1 \mathrm{a} \& 1 \mathrm{~b}$ respectively. Fig 1a shows a high porous nature and a coarse surface texture with pores of different shapes and sizes, but fig $1 \mathrm{~b}$ registers the effect of $\mathrm{Cu}(\mathrm{II})$ binding onto the adsorbent surface as cluster arrangement over the adsorption period. This is obvious from the distinct surface pores visible in $1 \mathrm{a}$, but unseen in $1 \mathrm{~b}$ indicative of adherence of the metal ion on TPJB.

\section{EDAX Analysis}

The EDAX spectra were recorded to analyze the elemental constitution qualitatively the \% of $\mathrm{O}, \mathrm{C}, \mathrm{Ca}$ and $\mathrm{Cl}$ being 47.13, 52.2, 0.58 and 0.09 respectively in TPJB. These have been reported as the principle elements of any adsorbent ${ }^{11}$. The new

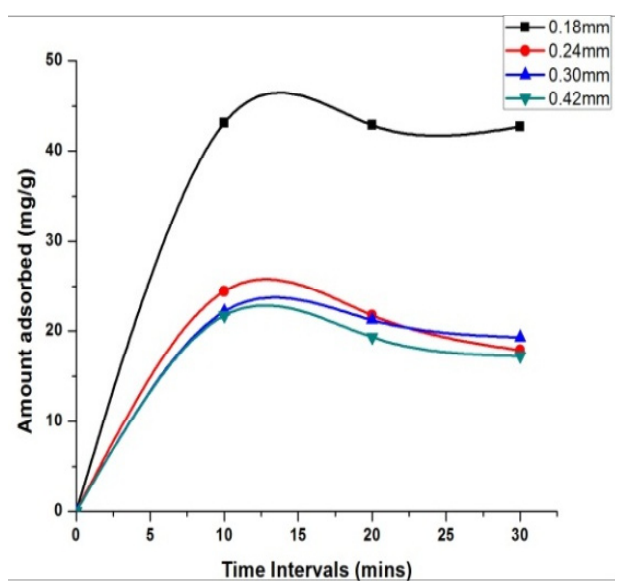

Fig. 3: Effect of Particle size

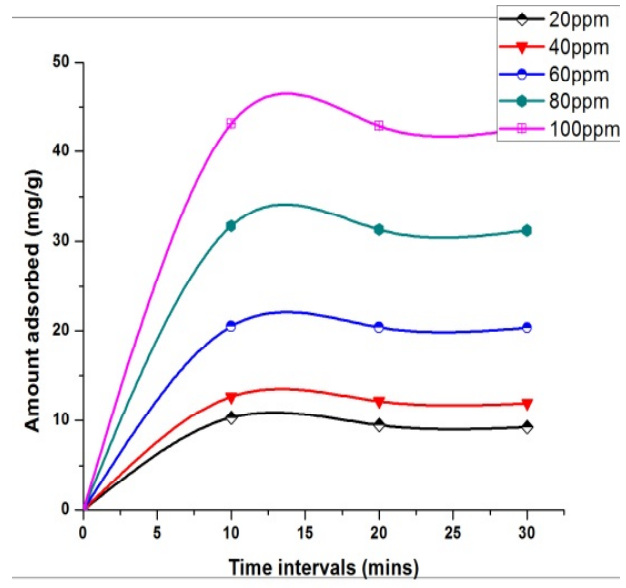

Fig. 4: Effect of Concentration peak at the energy range of $8-9 \mathrm{KeV}$ in figure $2 \mathrm{~b}$, confirms the $\mathrm{Cu}(\mathrm{II})$ adsorption onto TPJB.

\section{Effect of Particle size}

The influence of particle sizes of the modified material revealed that the uptake of ions increased with a decline in its size. The uptake to $\mathrm{Cu}$ (II) ions by $0.18 \mathrm{~mm}$ particle size of TPJB (fig 3 ) is observed as a smooth steep curve indicating greater amount adsorbed (44 $\mathrm{mg} / \mathrm{g}$ ) against other particle sizes $(0.18 \mathrm{~mm}, 0.24 \mathrm{~mm}, 0.30 \mathrm{~mm}$ and $0.42 \mathrm{~mm}$ ), the amount adsorbed range being 44 to $23.3 \mathrm{mg} / \mathrm{g}$. This can be attributed to the fact smaller the particle size, greater is the surface area per unit weight of the adsorbent ${ }^{12}$. Based on the statistical analysis mentioned in experimental part, the $p$ - value calculated for the influence of particle sizes are as follows. The model F-value is the ratio of mean square for the individual term to the mean square for the residual. The Prob $>\mathrm{F}$ value is the probability of F-statistics value and is used to test the null hypothesis. The parameters having an F-statistics probability value less than 0.05 are said to be significant. The P-value of 0.0497 at $95 \%$ confident level $(P<0.05)$ shows statistically that there is significant correlation in adsorption pattern. The negative correlation value $r=-7503$ were found between the particle sizes and the corresponding the values of amount adsorbed. The negative signs represented that as the particle sizes increased, the amount adsorbed values decreased.

\section{Effect of Initial concentration and Agitation time}

The initial metal ion concentration provides an important driving force to overcome all mass transfer resistance of $\mathrm{Cu}$ (II) between the aqueous and solid phase. The effect of time course profiles (10-30mins:10mins intervals) for the adsorption of ions under study at varied concentrations (20 to $100 \mathrm{mg} / \mathrm{L}$ ) is shown in figure 4. The initial uptake rate was very rapid and thereafter adsorption was gradual and an equilibrium was reached. About 98 $\%$ maximum removal of $\mathrm{Cu}$ (II) ions was registered at 10 min contact time, after which an equilibrium was attained. The metal uptake curve is single, smooth and continuous leading to saturation, suggesting the possible monolayer coverage of metal ions onto the surface of adsorbent (13). The P-value of 0.0045 at $95 \%$ confident level $(P<0.05)$ shows statistically 
that there is very significant correlation in adsorption pattern. The positive correlation coefficient $r=0.9759$ were found between the initial concentrations and the corresponding the values of amount adsorbed. The positive signs demonstrated that the patterns of changes in corresponding values were relatively similar.

\section{Effect of $\mathrm{pH}$}

The $\mathrm{pH}$ dependence of $\mathrm{Cu}^{2+}$ biosorption under optimized conditions onto TPJB is shown in Fig. 5. The inverted parabolic curve represents that maximum $\mathrm{q}_{e}$ had occurred at $\mathrm{pH} 9$, thereafter a decline was observed. The reduction can be attributed to the fact that the precipitation of ions occur during ion exchange experiments by $\mathrm{NaOH}$. Also, the lower $\mathrm{q}_{e}$ values at corresponding $\mathrm{pH}$ values indicate the competition between the protons $\left(\mathrm{H}^{+}\right)$ and metal ions $\left(\mathrm{Cu}^{2+}\right)$ for the exchange sites (14).

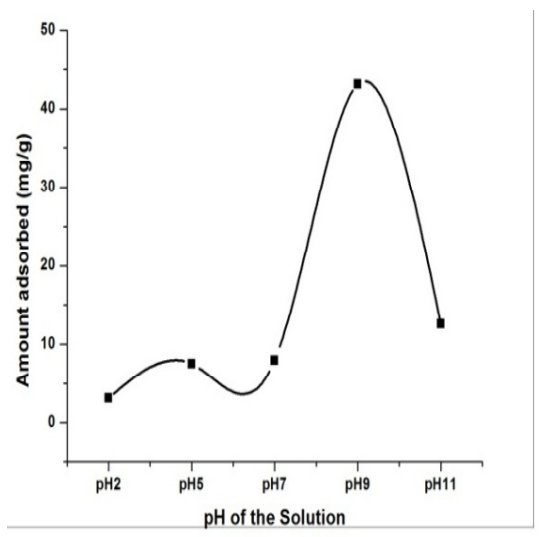

Fig. 5: Effect of pH

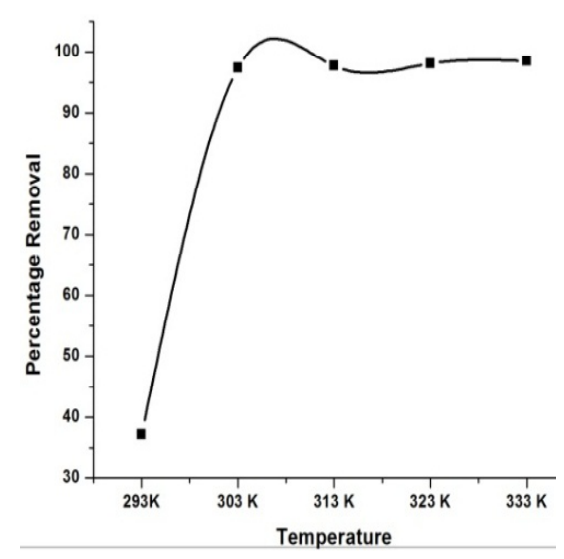

Fig. 6: Effect of Temperature
From the observation $\mathrm{pH} 9$ is declared as effective $\mathrm{pH}$ for maximum trapping of $\mathrm{Cu}(\mathrm{II})$ by TPJB. The $P$-value of 0.0355 at $95 \%$ confident level $(P<0.05)$ shows statistically that there is significant correlation in adsorption pattern. The positive correlation coefficient $r=5356$ were found between the $\mathrm{pH}$ and the corresponding the values of amount adsorbed.

\section{Effect of Temperature}

Temperature has a pronounced effect on the adsorption capacity. Fig 6 reveals that the removal of $\mathrm{Cu}(\mathrm{II})$ registered a sudden increase (38\% to $97.4 \%$ ) from $293 \mathrm{~K}$ to $303 \mathrm{~K}$ after which the curve reached a plateau nature, with increase in temperature up to $313 K^{15,16,17}$. The higher percentage removal may be attributed to the fact that increased temperature rises the mobility of $\mathrm{Cu}(\mathrm{II})$ ions facilitating enhanced adsorption. The P-value of 0.465 at $95 \%$ confident level $(P<0.05)$ shows statistically that there is significant correlation in adsorption pattern. The positive correlation coefficient $r=7178$ were found between the temperature and the

Two way ANOVA results of various parameters are given in table 2 . The linear regression plots of various parameters are given below

\section{Langmuir Isotherm}

The Langmuir sorption isotherm describes the removal of adsorbate that had occurred on a homogeneous surface by monolayer sorption, without interaction between adsorbed molecules ${ }^{18}$

The Langmuir constants $\mathrm{q}_{\mathrm{m}}$ and $\mathrm{b}$ were determined from the linear plot (fig 7) of $\mathrm{C}_{e} / q_{e}$ versus

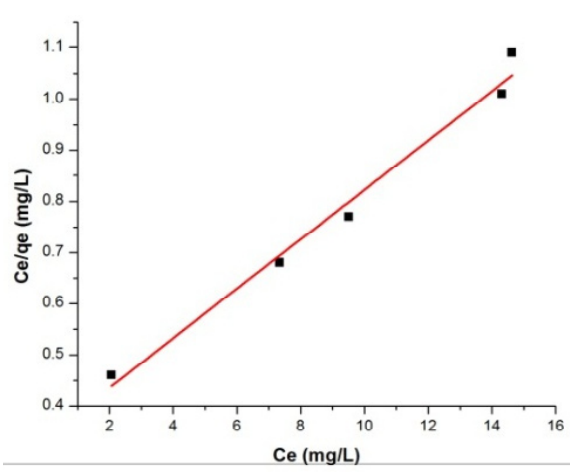

Fig. 7: Langmuir Isotherm 
$C$, with a slope of $1 / q_{m}$ and intercept of $1 / b$ (table $3)$. Higher the value of $b$, higher is the affinity of adsorbent for the metal to be sorbed ${ }^{19}$

The essential characteristics of Langmuir isotherm can be expressed in terms of a dimensionless parameter called the separation factor or equilibrium parameter $R_{L}$, which is defined by the following relationship ${ }^{20}$

where, $C_{i}$ is the initial metal ion concentration (mg/L). The parameter $R_{L}$ indicates the shape of the isotherm and the nature of the sorption process ${ }^{21}$

The correlation coefficient values $\left(R^{2}\right)$ for the metal is approximately 0.9851 (Table 4). The $R_{L}$ values for $\mathrm{Cu}$ (II)-TPJB lying between 0.01 and 0.74 (table 3) indicate favourable adsorption.

\section{Freundlich Isotherm}

The Freundich equation is commonly used for mathematical description of adsorption in

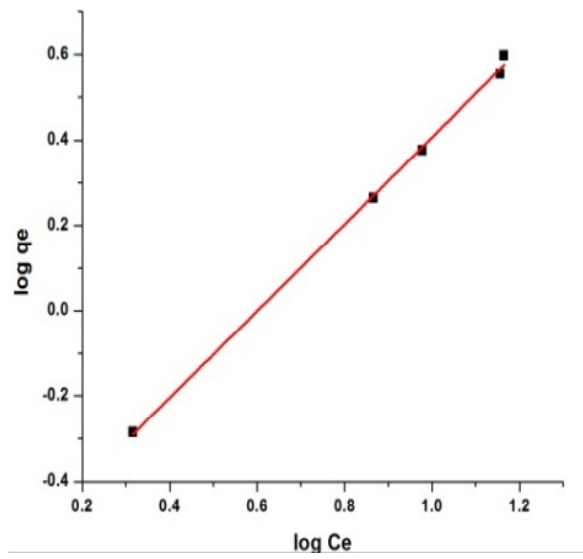

Fig. 8a: Freundlich Isotherm aqueous system. $\mathrm{K}_{\mathrm{f}}$ and $1 / \mathrm{n}$ are Freundlich constants related to adsorption capacity and adsorption intensity, respectively. Both $\mathrm{K}_{\mathrm{f}}$ and $1 / \mathrm{n}$ are empirical constants being indicative of sorption capacity and adsorption intensity, respectively ${ }^{22}$

Freundlich constants (adsorption capacity and adsorption intensity) were calculated from the linear plot. Both $K_{f}$ and $1 / n$ are empirical constants being indicative of sorption capacity and adsorption intensity, respectively ${ }^{23}$. From the slope and intercept of plots $\log q_{e}$ vs $\log C_{e}$ (fig 8), values of $K_{f}$ and $R^{2}$ were determined (table 4$)$. The $R^{2}$ values (0.9985) from the plot suggests maximum linearity and the better fit in of $\mathrm{Cu}(\mathrm{II})$-TPJB on Freundlich adsorption isotherm.

\section{Tempkin Isotherm}

Tempkin isotherm equation contains a factor that explicitly takes into account adsorbent-adsorbate interactions. It assumes that the heat of adsorption of all the molecules in the layer decreases linearly with

Table 2: Descriptive analyses results for the different parameters

\begin{tabular}{|c|c|c|c|c|c|c|}
\hline $\begin{array}{l}\text { Dependent } \\
\text { Variables }\end{array}$ & $\begin{array}{l}\text { Sum } \\
\text { Square }\end{array}$ & $\begin{array}{l}\text { Degree of } \\
\text { Freedom }\end{array}$ & $\begin{array}{l}\text { Mean } \\
\text { Square }\end{array}$ & $\begin{array}{c}F \\
\text { (POS) }\end{array}$ & $\begin{array}{l}\text { Standard } \\
\text { Deviation }\end{array}$ & $\begin{array}{l}\text { Standard } \\
\text { Error }\end{array}$ \\
\hline Particle Size & 314.4 & 4 & 68.71 & 2.576 & 10.237 & 5.119 \\
\hline Dosage & 752.53 & 4 & 11.93 & 60 & 13.716 & 6.134 \\
\hline $\mathrm{pH}$ & 743.72 & 4 & 247.91 & 1.205 & 16.144 & 7.22 \\
\hline Temperature & 1430.4 & 4 & 476.81 & 3.188 & 27.16 & 12.15 \\
\hline
\end{tabular}

$\mathrm{POS}=$ probability of F-statistics 


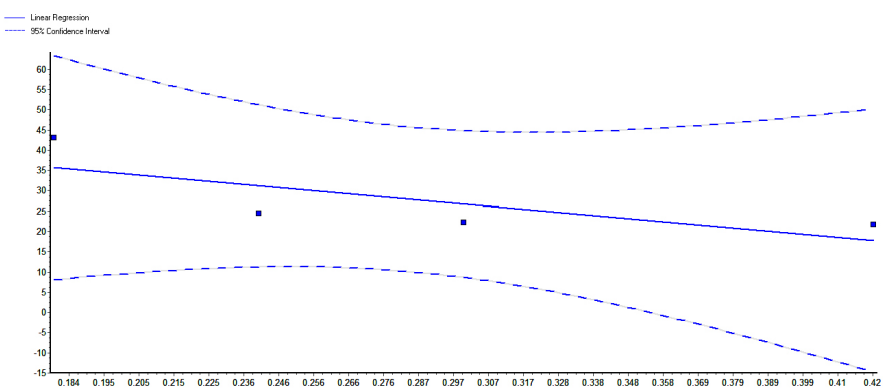

Linear regression curve for the effect of particle size

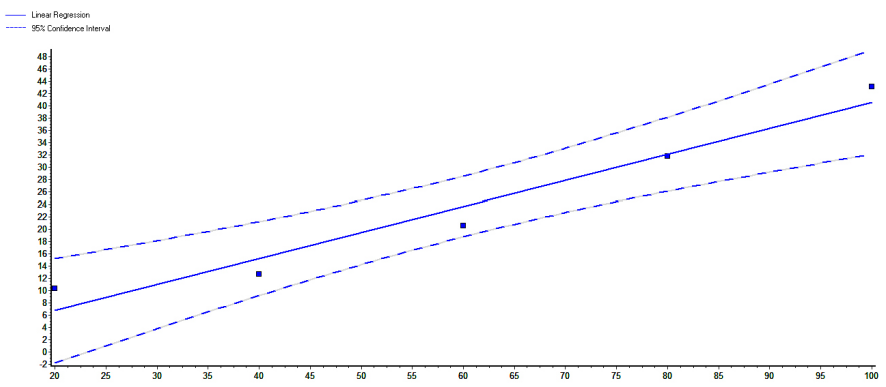

Linear regression curve for the effect of Initial Concentration

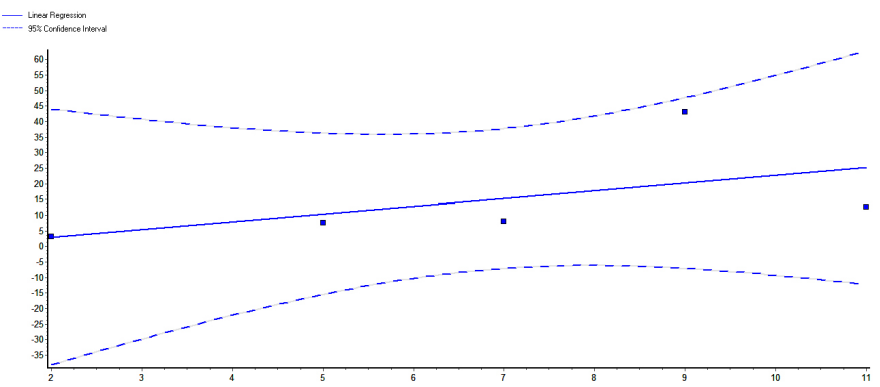

Linear regression curve for the effect of $\mathrm{pH}$

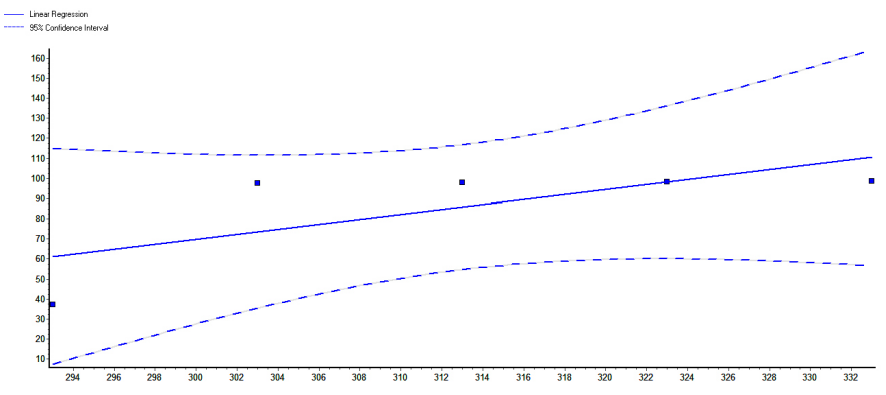

Linear regression curve for the effect of temperature 


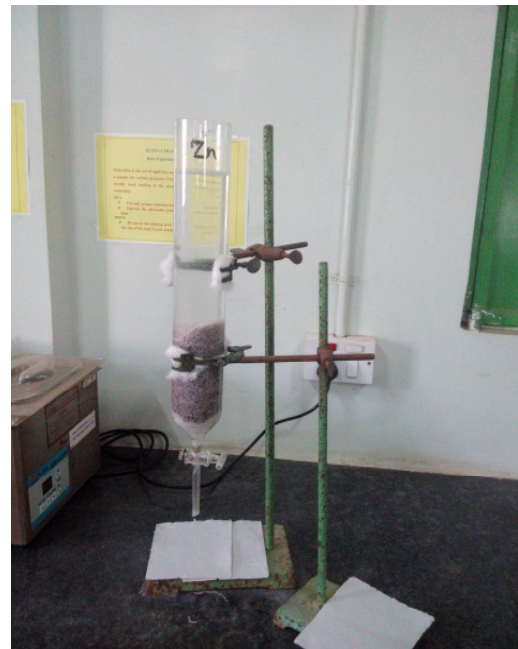

Fig. 9

Table 3: Equilibrium parameter RL for Cu(II) system

\begin{tabular}{ll}
\hline Conc. ofmetal ion (mg/L) & $\mathrm{Cu}(\mathrm{II})$-TPJB \\
\hline 20 & 0.26 \\
40 & 0.15 \\
60 & 0.1 \\
80 & 0.08 \\
100 & 0.07 \\
\hline
\end{tabular}

Table 4: Isotherm constants

\begin{tabular}{ll}
\hline $\begin{array}{l}\text { Isotherm } \\
\text { parameters }\end{array}$ & Cu(II) -TPJB \\
\hline $\begin{array}{l}\text { Langmuir isotherm } \\
\text { qm (mg/g) }\end{array}$ & 20.73 \\
b (L/g) & 0.1424 \\
R2 & 0.9851 \\
Freundlich isotherm & \\
KF (mg/g) & 4.0945 \\
n & 0.9815 \\
R2 & 0.9985 \\
Tempkin isotherm & \\
AT (L/g) & 4.9762 \\
bT & 1.0493 \\
R2 & 0.9661 \\
\hline
\end{tabular}

coverage due to adsorbate-adsorbate repulsions and the adsorption is a uniform distribution of maximum binding energy ${ }^{24}$.

$$
\mathrm{R}_{\mathrm{L}}=\frac{1}{\left(1+\mathrm{b} \mathrm{C}_{\mathrm{i}}\right)}
$$

where, $B T=R T / b T$, $T$ is the absolute temperature in Kelvin and $R$ is the universal gas constant, $8.314 \mathrm{~J} / \mathrm{mol} \mathrm{K}$. The constant bT is related to the heat of sorption. The constant AT is the equilibrium binding constant corresponding to the maximum binding energy.

Tempkin isotherm was applied to the adsorption data under investigation, as per equation ${ }^{6}$. Tempkin constants $A_{T}$ and $b_{T}$ corresponding to the equilibrium binding constant and heat of adsorption are obtained from the linear plot of $\ln \mathrm{C}_{\mathrm{e}}$ versus $\mathrm{q}_{\mathrm{e}}$ (fig. 9).

The constants and the correlation coefficient values (table 4$)$ imply that Tempkin $\left(R^{2}=0.9661\right)$ and Langmuir $\left(R^{2}=0.9851\right)$ isotherms are obeyed by the system less effectively when compared to Freundlich model $\left(R^{2}=0.9985\right)$.

\section{Column Studies}

From the optimized batch equilibration results, Column studies were performed to quantify the removal of $\mathrm{Cu}$ (II)-TPJB system. Fixed-bed columns, made of cylindrical glass tube $(2.5 \mathrm{~cm}$ inner diameter and $30 \mathrm{~cm}$ height) were packed with the TPJB between two supporting layers of glass wool, spread with the glass beads at the bottom layer of glass wool. TPJB were loaded from the top of the column and allowed to settle by gravity force. $100 \mathrm{ppm}$ of $\mathrm{Cu}$ (II) solution was added from the top and the flow rate was adjusted by collection of $5 \mathrm{ml}$ of the sorbate at 10 minutes time interval. The maximum removal of TPJB was registered as $98 \%$.

\section{CONCLUSION}

The selected agricultural waste (Prosopis juliflora) was modified using $\mathrm{HCl}$ for the removal of $\mathrm{Cu}$ (II) ions. The physio chemical characteristic studies viz., pH, conductivity, moisture content, bulk density, specific gravity, porosity, ash content and 
elements $(\mathrm{C}, \mathrm{H}, \mathrm{N}, \mathrm{S})$ were determined. The surface morphological changes, elemental constitutions and surface area of TPJB were determined using SEM, EDAX and BET respectively for unloaded and loaded material. The changes in porosity structure (SEM) and the appearance of $\mathrm{Cu}(\mathrm{II})$ peaks in the EDAX images support the adsorption positively. The Batch equilibration conditions for maximum percentage removal (98\%) of $\mathrm{Cu}(\mathrm{II})$-TPJB system was optimized at: $0.18 \mathrm{~mm}$ particle size, $200 \mathrm{mg}$ dosage, 10 minutes agitation time, $100 \mathrm{mg} / \mathrm{L}$ initial concentration of $\mathrm{Cu}(\mathrm{II})$ ions, $\mathrm{pH} 9$ of the solution medium at $30^{\circ} \mathrm{C}$. Isothermal analysis of the data emphasized that the adsorption pattern exhibited a better fit for Freundlich isothermal plot than other all isothermal studies (Langmuir and Tempkin). Experiments were performed to assess the efficiency of TPJB through continuous column running for quantitative estimation of $\mathrm{Cu}(\mathrm{II})$ removal from the bulk of the solution. The statistical output data for viz., particle sizes, initial $\mathrm{Cu}$ (II) concentrations, dosages, $\mathrm{pH}$ of the solutions and temperatures had a significant effect on $\mathrm{Cu}$ (II) adsorption. A good correlation between the input and output variables is observed by applying SPSS 20 software.

\section{REFERENCES}

1. Amudaa, O.S.; Giwa, A.A.; Bello, I.A. Biochem. Eng. J. 2007, 36, 174-181.

2. Mohammad, W; Amer, Fawwaz I. Khalili; Akl M. Awwad. J. Env. Chem.\& Ecotoxi. 2010, 2(1), 001-008.

3. Karthika, C; Sekar, M. Res. J. Chem. Sci. 2013, 3(3), 65-69.

4. WHO, Guidelines for Drinking- Water Quality (1984).

5. Sureshkumar; Halnor Maqdoom Farooqui; Milind Ubale, Inter.J. Appl. Inno. Engin.\& Manag. 2013, 2(3), 125-135.

6. Nazar Abdualaziz Elnasri Hamza; Almoeiz Yousif Hammad; Mohammed Abuzeid Eltayeb, Sci J. of Analy. Che., 2013, 1(2), 12-20.

7. HakanDemiral; IllknurDemiral; FatmaTumsek; Belgin Karabacakoglu, Chem. Eng. J. 2008, 144, 188-196.

8. Demirbas, E; Kobya, M; Konukman, A.E.S. J. Hazard. Mater. 2008, 154, 787-794.

9. Efficient adsorption of $\mathrm{Cr}(\mathrm{VI})$ from aqueous solution on low cost adsorbent developed from Limonia acidissima (Wood apple) shell. Ads. Sci.\& Tech., 2010, 28 (6), 547-560.

10. El-Ashtoukhya, E.-S.Z; Amina, N.K; Abdelwahab, O. Desal. 2008, 223, 162-173

11. Adie, D.B; Okuofu, C.A; Osakwe, C; Inter. J. of Appl. Sci.\& Tech., 2012, 2(7), 165-172

12. Michael Horsfall Jnr; Jöse L. Vicente, Bull.
Chem. Soc. Ethiop., 2007, 21(3), 349-362

13. Sivakumar, K.K; Dheenadayalan, M.S; Eur. Chem. Bull. 2012, 1(5), 161-167

14. Makeswari, M; Santhi, T. Arab. J. Chem. 2014

15. Montanher, S.F.; Oliveira, E.A.; Rollemberg,M.C. J. Hazard. Mater., 2005, 117, 207-211.

16. Karthikeyan, T.; Rajagopal, S.; Lima Rose Miranda. J. Hazard. Mater.,2005, 124, 192199.

17. Bethedsa, MD; National toxicology information Program, National Library of Medicine. 1993

18. Minaxi, B; Lohani; Amarika Singh; Rupainwar, D.C; Dhar D.N. J. Hazard. Mater., 2008, 159, 626-629.

19. Gupta, V.K; Rastogi, A. J. Hazard. Mater., 2008, 152, 407-414.

20. Kumar, M; Tamilarasan, R; J. of Chem. Tech., 2013, 15(2), 29- 39.

21. Zabihi, M; Ahmadpour, A; HaghighiAsl, A. J. Hazard. Mater., 2009, 167, 230-236

22. Hanim Awab; Thanalechumi Paramalinggam, J. of Fund. Sci., 2012, 7(2), 113-119.

23. Zouhair Elouear, J; Bouzid and, N; Boujelben. Worldwide workshop for young Environmentalists, 2010

24. Stella Triyantafylou; Eirini Christoudolou; Paraskevi Neou-Singouna. Clay \& Clay Min. 1999, 47, D567-572. 